\title{
REINDUSTRIALIZATION: A CHALLENGE TO THE ECONOMY IN THE FIRST QUARTER OF THE TWENTY-FIRST CENTURY
}

\author{
Michał KRAWCZYŃSKI*, Piotr CZYŻEWSKI**, Karol BOCIAN*** \\ Warsaw University of Technology, Faculty of Management, Poland \\ *e-mail: m.krawczynski@wz.pw.edu.pl \\ **e-mail: czyzewski.piotrek@gmail.com \\ ***e-mail: bocian.karol@gmail.com
}

\begin{abstract}
The weakening EU and US economies in the aftermath of the global crisis of 2007 need an impulse to act for the improvement of their condition. The analysis of the history of the GDP of selected world economies suggests that a remedy for it may be the strengthening of the industrial sector. By strengthening, we mean its growth, that is, building and developing manufacturing plants. Large multinationals have generally been relocating their production to China, where labor costs have traditionally been a couple of times lower than in the US or the EU. However, over the past years, the pay gap between the US and China has narrowed, and transport prices have gone up. These are the reasons why numerous large American companies decided to transfer part of their business processes back to the homeland. Also, the EU has been taking account of the benefits of a stable industry. Therefore, it has launched the strategy of "European industry rebirth" that entails a growth of the industry's share in the GDP up to the level of $20 \%$. In order for EU countries to be able to attain it, the paper raises the issue of the Industrie 4.0 methodology, premises and guidelines may, to a large extent, contribute to success. The paper also takes an in-depth look at Industrie 4.0 and discusses its pros and cons. We attempt to provide an answer to the question of whether Industrie 4.0 may be a tool for reindustrialization.
\end{abstract}

Keywords: reindustrialization, European Union, Industrie 4.0, 2007 crisis.

\section{The origins of reindustrialization}

March 2010 saw the implementation of the strategy "Europe 2020 - a European strategy for smart, sustainable, and inclusive growth". It includes, among others, initiatives that are of key importance for the growth of industrial competitiveness in the EU, that is, "Innovation Union", "Digital Agenda for Europe", "Integrated Industrial Policy for the Globalisation Era", and "New Skills for New Jobs" (Komisja Europejska [UE Commission], 2012). The Commission's Communication "Industrial Policy: Reinforcing Competitiveness" of 2011 urged to introduce changes whose aim would be the improvement of the EU's economic and industrial competitiveness and supporting a long-term and balanced growth (Komisja Europejska [UE Commission], 2011). In turn, the Commission's Communication "A Stronger European Industry for Growth and Economic Recovery - Industrial Policy Update" of 2012 aimed at supporting innovation investments (Komisja Europejska [UE Commis- sion], 2012). It took into account, above all, advanced productive technologies in such fields as ecologically clean production, key assistive technologies, bio-products, balanced industrial policy, building engineering and raw materials, clean vehicles and ships, as well as intelligent networks. The subsequent Commission's Communication of 2014 "For a European Industrial Renaissance" stresses the significance of reversing the situation in declining industry and increasing the share of production in the GDP up to $20 \%$ by 2020 (Komisja Europejska (UE Commission, 2014). The need was presented to draw up a more coherent policy in the area of internal market (energy, transport, and information infrastructure), as well as commodity, services, administration, trade, research, and raw materials (Gouardères, 2016).

The following question comes to the fore: does the return of economy to reindustrialization make sense, or does it result only from the recommendation of the European Union? While trying to find the answer, the changes of the industry share in gross 
domestic product (GDP) have been scrutinized in different countries over the past few years. The significance of a given country for global economy and the characteristics of its economy (the biggest percent share of a given economy sector in the GDP all over the world) were taken into account, that is:

- the European Union,

- China,

- the US,

- France (the biggest share of services in the GDP worldwide),

- India (the biggest share of agriculture in the GDP worldwide),
- Saudi Arabia (the biggest share of industry in the GDP worldwide).

Three economic sectors were taken into account as the most significant ones: agriculture, industry, and services. The change of relation between industry share and services share in making GDP in the years of crisis and the following years was analyzed. The diagram presented below (Fig. 1) shows the share of a given country in global GDP. The data depicted on the diagrams concerning GDP were gained from two sources (Eurostat, 2016; Index Mundi, 2015); thus, they can vary due to different modes of calculating GDP.

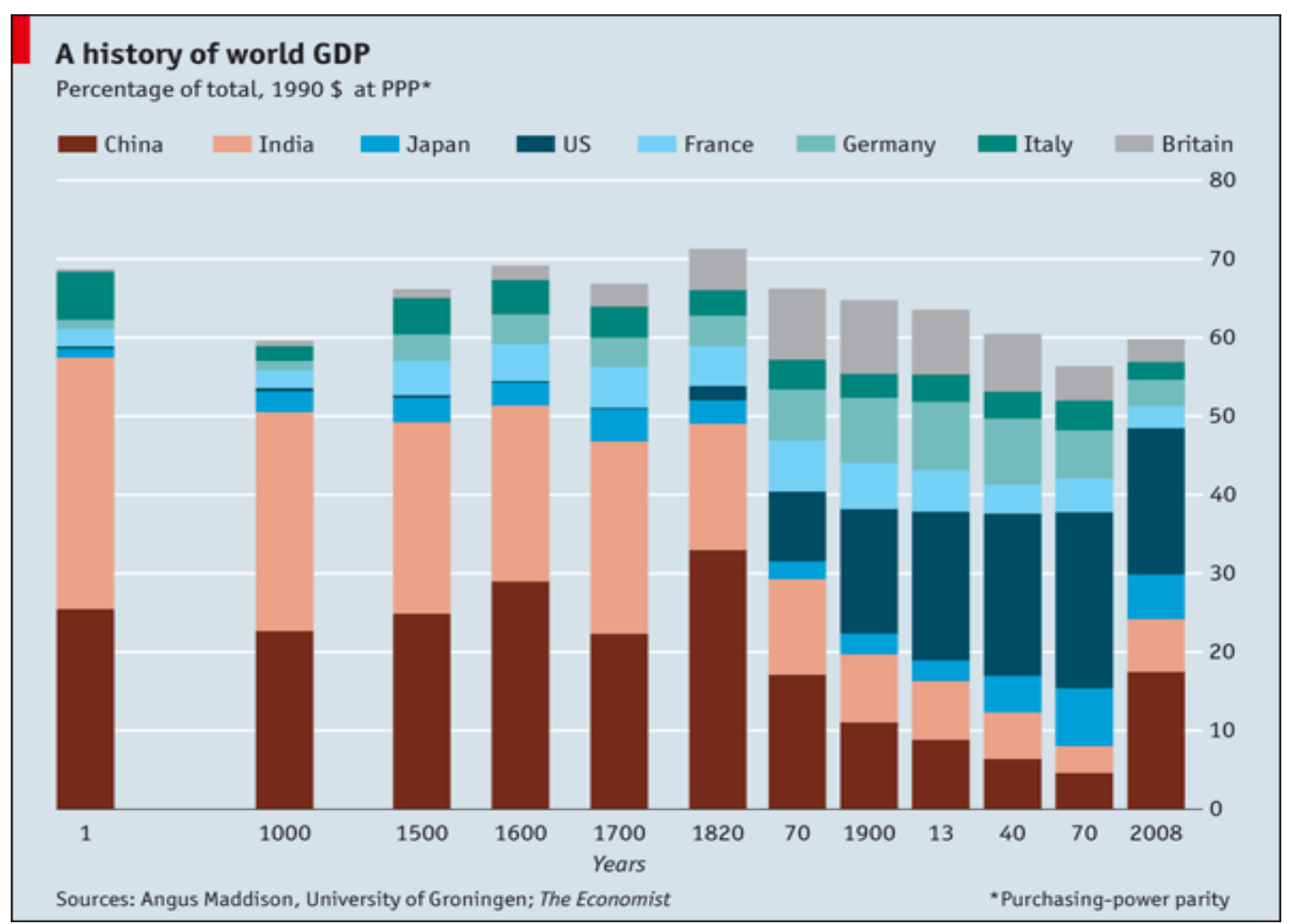

Figure 1. Countries' share in the global GDP over the past 2000 years (source: Ritholtz B., 2010)

The chart (Fig. 1) illustrates a synthesis of the economic history of human civilization. The value of individual contributions has been influenced by numerous events and decisions made. It is clear to see, for example, that at the beginning of our era, the value of generated GDP was strongly correlated to a given country's population. This period reveals a major share of these countries in the global GDP.
One should also note the exceptional heyday of the US. The underlying causes of this success could well occupy an entire book. Amidst a variety of reasons, the following ought to be remembered: lack of legal restrictions, outstanding economic freedom, a wealth of natural resources, and the growth of heavy industries. 
At the same time, China's and India's share has been decreasing at a high pace, as population rates systematically have an increasingly smaller impact, giving way to the growing importance of technological advancement. Over the past two decades, China has returned to its previous role. It owes it, among others, to cheap human labor, rising taxes, and the inflation of legislation within the EU and the US, which has made these countries far less competitive.

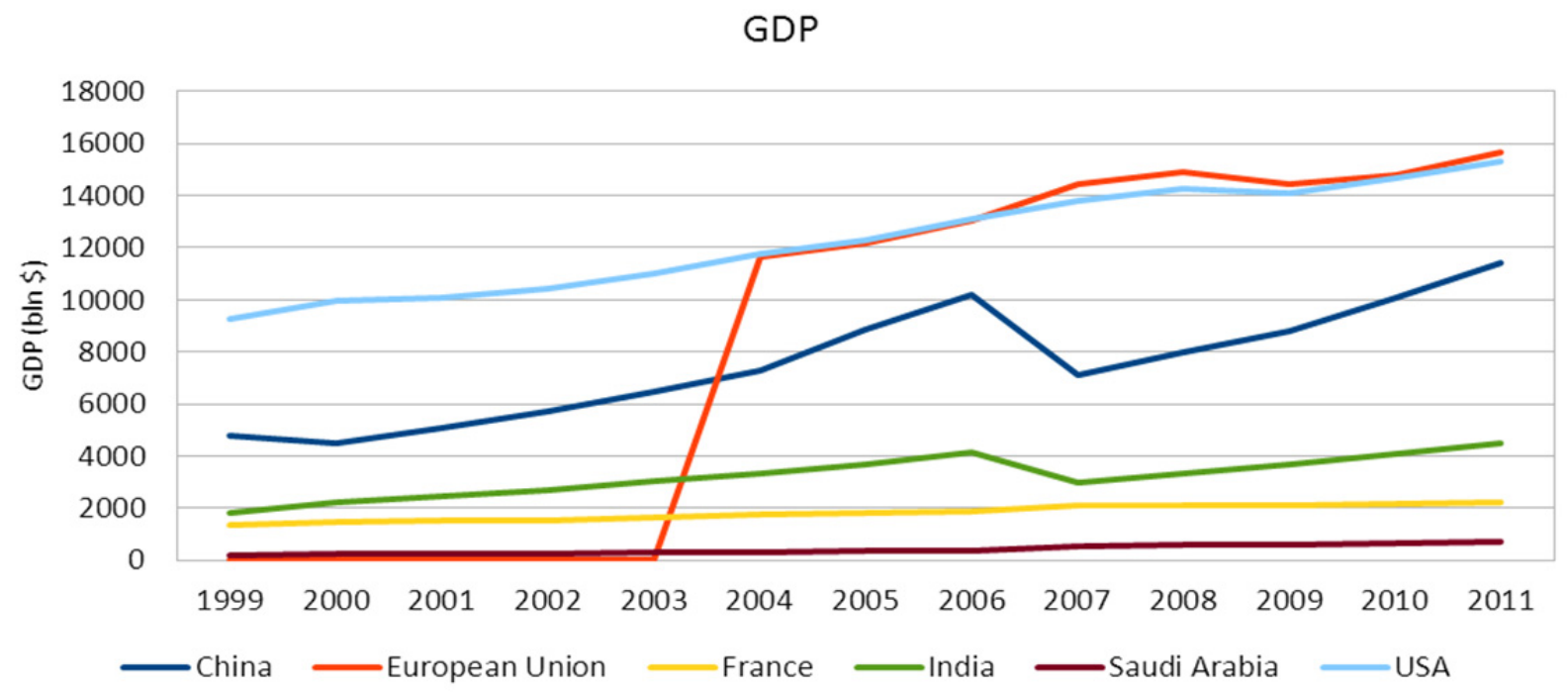

Figure 2. Change in GDP in the years 1999-2011

(source: based on: Index Mundi, 2015)

Figure 2 shows the history of the GDP of selected countries in the years 1999-2011, calculated in billions of US dollars. It is clear to see that all the indi- cators of the countries in question witnessed a growing trend in the period prior to the crisis. The biggest drop was seen in China.

\section{Percentage change of GDP}

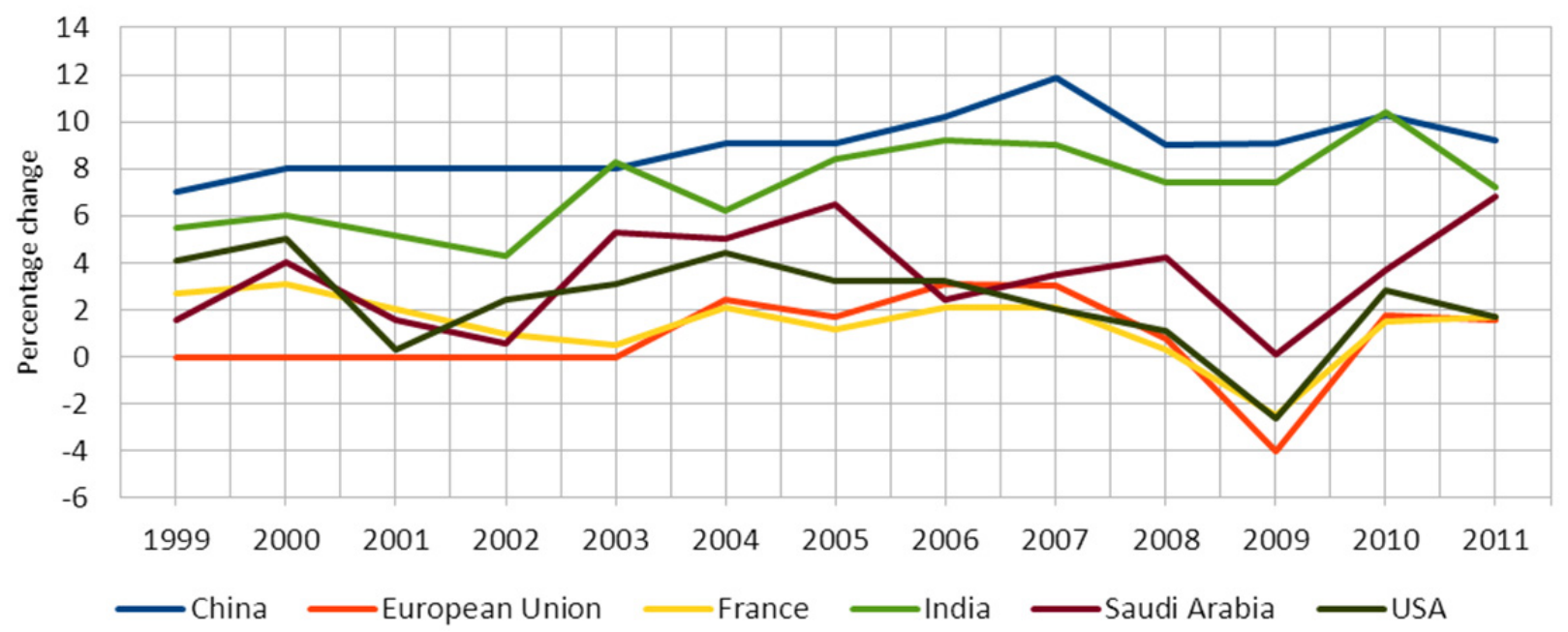

Figure 3. The pace of GDP growth in the years 1999-2011 (source: based on: Index Mundi, 2015)

The graph in the Fig. 3 illustrating the percentage change of GDP shows that western countries were deeply affected by the financial crisis of 2009 . Yet, even countries not directly hit by the crisis took it badly, mostly because of strong large economic dependence from the US and the EU. 


\section{Percentage change of GDP}

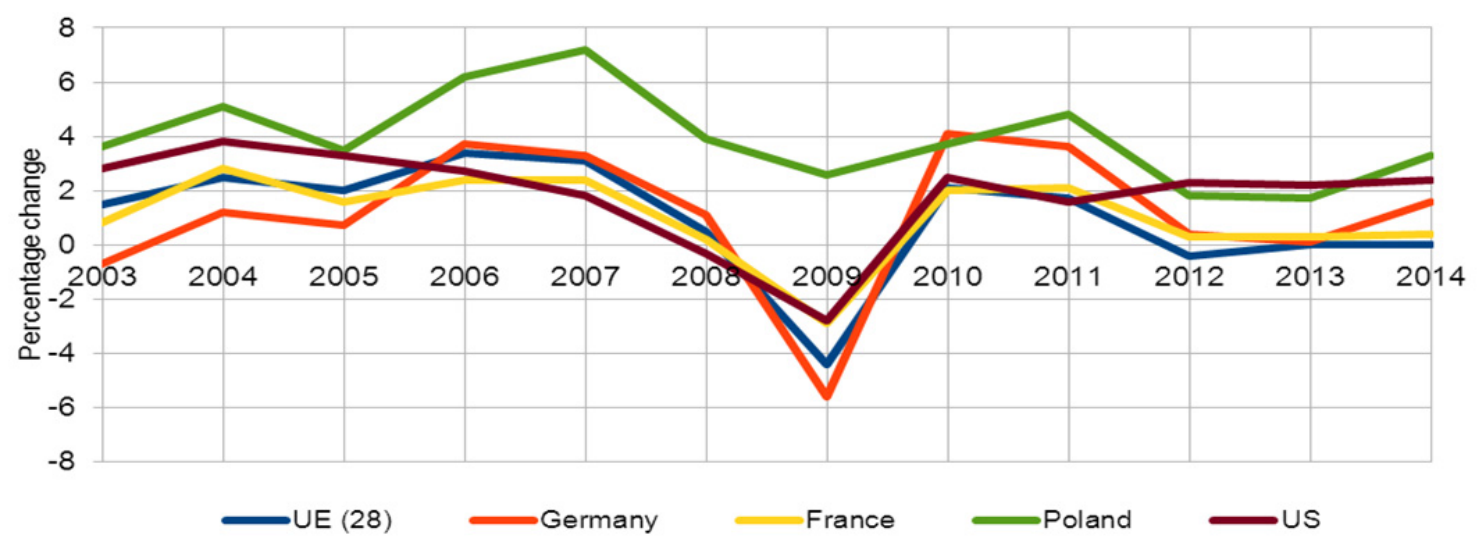

Figure 4. The pace of GDP growth in the years 1999-2011

(source: Komisja Europejska [UE Commission], 2012)

The graph in the Fig. 4 showing the percentage change of the GDP proves that the crisis affected all the EU countries. Also, EU enlargement, hosting a few new countries, caused a drop in GDP growth. It is worth noting that Poland was the only exception in this case.

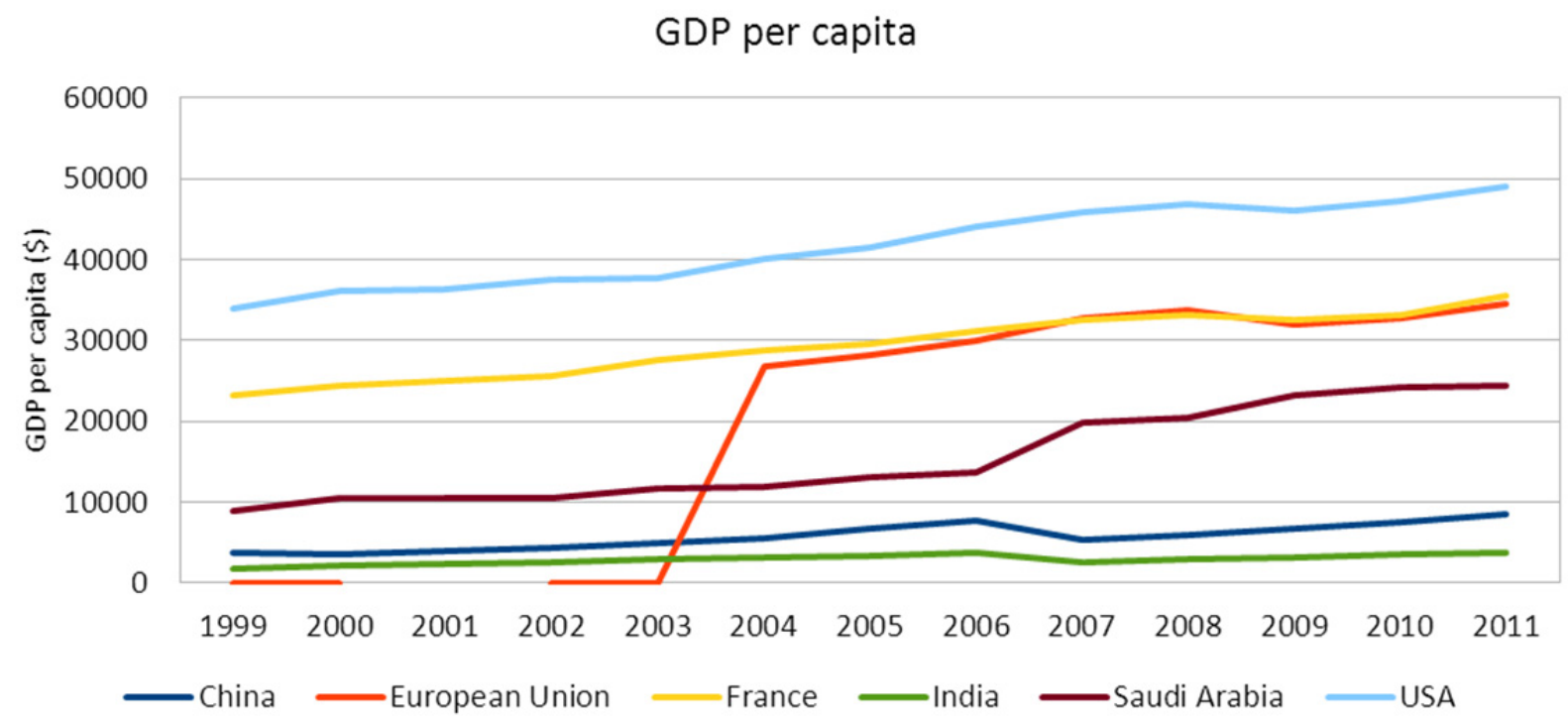

Figure 5. GDP change per inhabitant in the years 1999-2011

(source: based on: Index Mundi, 2015)

In all the countries considered, there is a discernible tendency for a growing value of GDP per capita. In these countries, except Saudi Arabia, one can still see repercussions of the crisis, which is most probably due to the fact that Saudi Arabian industry owns an over $60 \%$ share in the GDP.

The last graph (Fig. 5) shows the GDP of countries subjected to analysis, divided into sectors of the economy: agriculture, industry, and the service sec- tor. It is easy to notice that in western countries, the share of services in the GDP exceeds $70 \%$, whereas in the remainder, it is decisively lower: $45 \%$ for China and 35\% for Saudi Arabia. In China's case, the share of services and the industry is almost equal. It is also worth stressing that only in China and India does the share of agriculture exceed $10 \%$. In the other countries, it is merely a few percent 


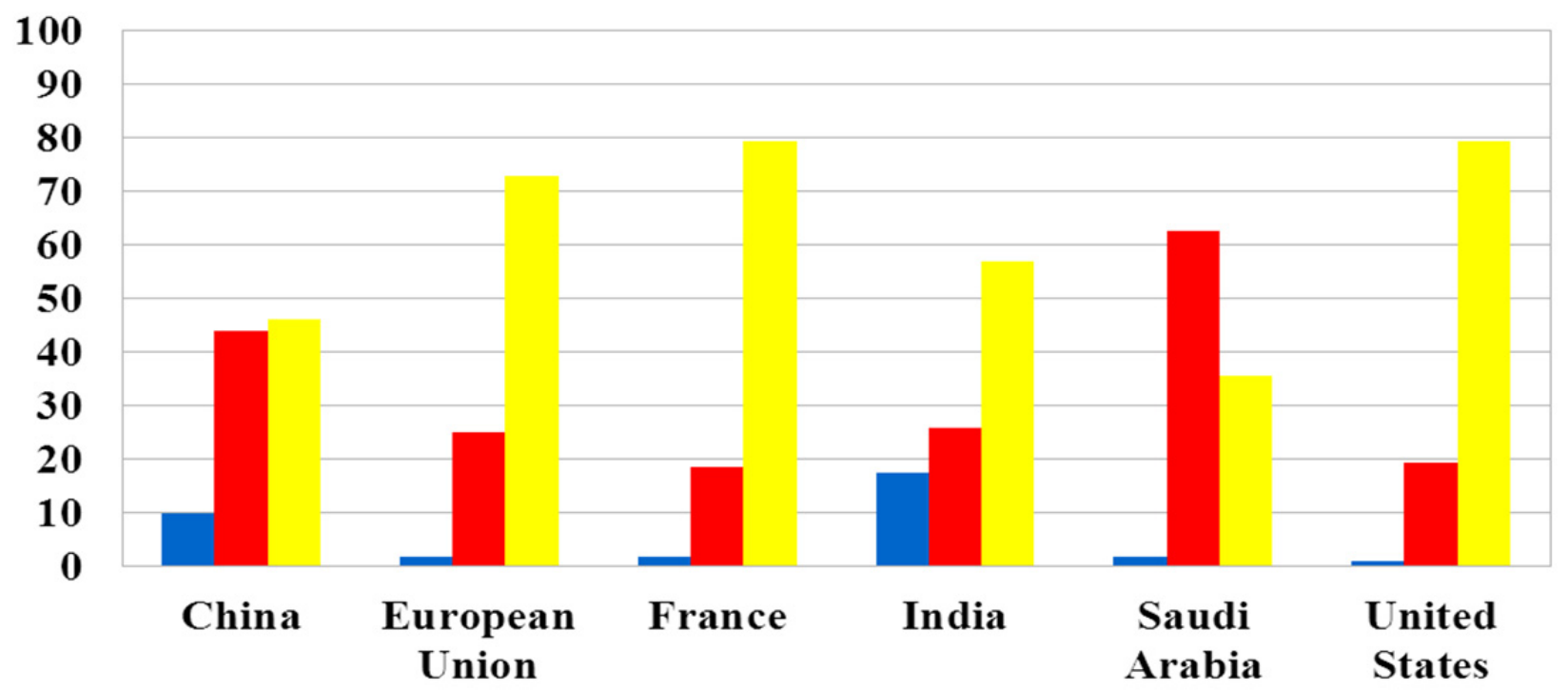

Agricultural $\approx$ Industrial $\quad$ Service

Figure 6. The characteristics of the economies of selected countries in 2014

(source: Global Finance, 2016; Wikipedia, 2015)

The data from Fig. 6 allows to draw the following conclusions:

- countries with a major share of their industries in GDP growth have gone through the years of global crisis a lot better,

- making the economy rest on services was one of the causes of the crisis that took place (primarily when it comes to financial services),

- while making it through the crisis, one should imitate the countries that have suffered the least in the years of the crisis, or the crisis did not affect them in a major way,

- protective measures against a new crisis ought to be sought in a growing share of the industry in generating the GDP,

- increasing the industry's share in the GDP implies its growth using innovative solutions within designing new technologies and IT solutions, which means that we should witness reindustrialization in a manner that is adequate to the changing geopolitical conditions,

- it is possible to assume that significant financial means will shortly be devoted to increasing the share of the industry, including reindustrialization; this will involve both individual countries and the EU.

\section{The history and trends of the growth of industrial activity}

In order to better outline the trends of the growth of industrial activity, it is necessary to refer to the history of industrial growth. Fig. 7 is its simplified, but still meaningful, scheme.

The history of the industry is directly connected to scientific and technological discoveries. It is assumed that until now, there have been three breakthrough discoveries: the steam engine, the assembly line, and the programmable logic controller (PLC). Each of them pushed a subsequent phase of industrial growth. It is estimated that by 2020 , the industry will have undergone so enormous technological and organizational changes that one will speak of a further stage of development. 


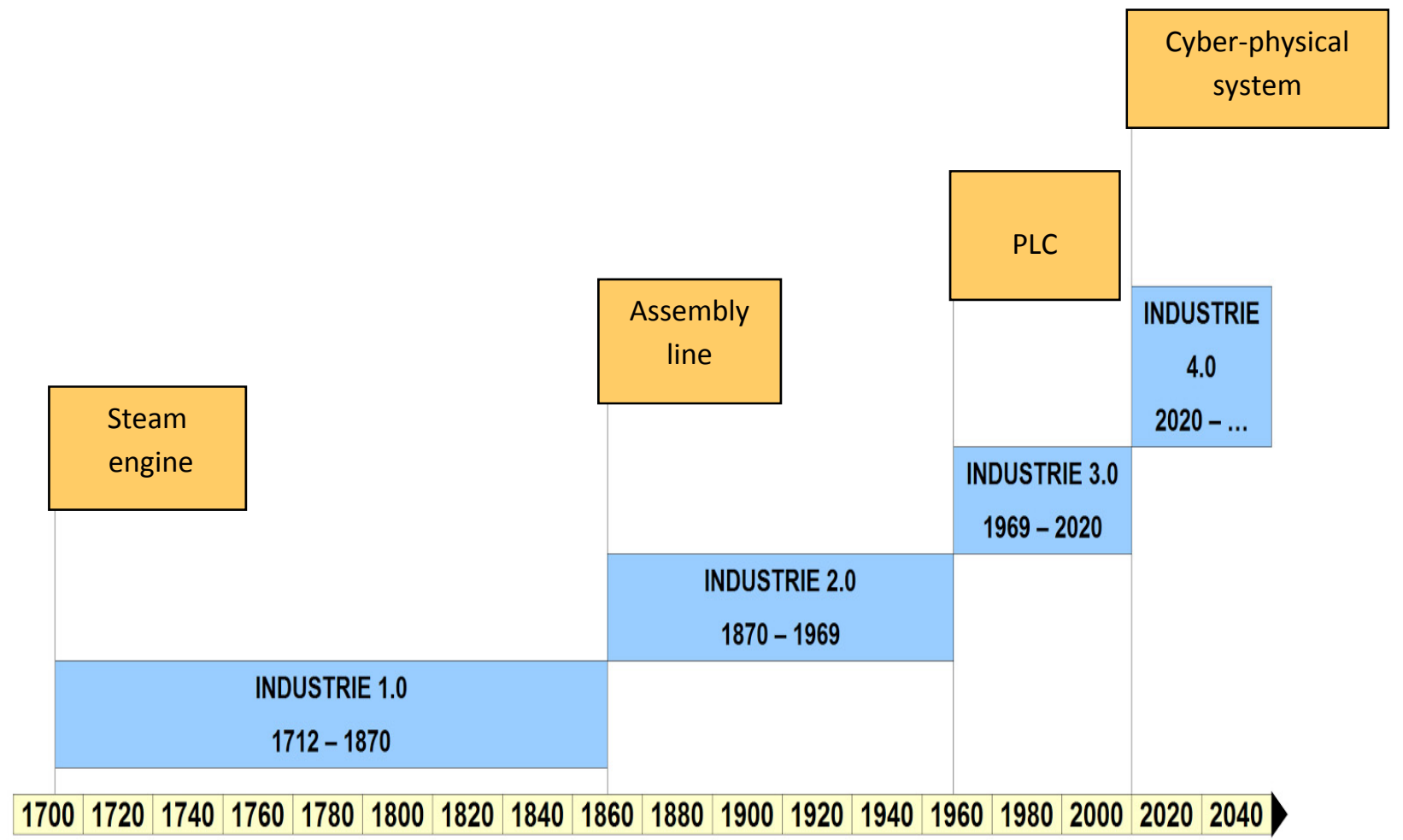

Figure 7. The history of the industry

(source: based on: Bocian, Czyżewski and Nowakowski, 2015)

\subsection{Industrie 1.0}

The first breakthrough discovery was the steam engine, brought to life in the eighteenth century in Britain. Implementation of this discovery paved the way for the Industrial Revolution. Efficiency of factories and manufacturing plants rocketed in an unprecedented way. The discovery sped up the transformation of manufactures into factories. Soon after, began the Second Industrial Revolution, which was caused by a quick growth of technology and sciences. The iron/steel industry and the metallurgical industry developed; also the automotive industry took shape, and, the industry saw the utilization of electrical energy.

\subsection{Industrie 2.0}

Industrie 2.0 took place in the years 1870-1969. A breakthrough discovery was the use of an assembly line by Henry Ford in 1913 for the first time in the world (Fig. 8). It gave rise to mass production. The time needed to assemble a vehicle in an assembly line was already at the beginning shortened from
12.5 to 1.5 hours. The use of an assembly line increased the number of Model T cars produced from 78,000 (1912-1913) up to 248,000 (1913-1914).

The Third Industrial Revolution, also known as the Digital Revolution, is a process of rapid changes within science, technology, and manufacturing. It began in the aftermath of the Second World War and it is still going on (GeoGrześ, 2010).

\subsection{Industrie 3.0}

The third wave of industrial growth is, above all, the computerization of the manufacturing industry. Its origins date back to 1969 , at the time when the first PLC was developed. It made it possible to control machine operation, devices, and technological sequences by dint of a microcontroller. On its basis, expanded systems of Supervisory Control and Data Acquisition, as well as Distributed Control Systems. The era of computer-assisted engineer design was born. Increasingly more workplaces were computerized, and everything was connected via the Internet: at first, a local network and later, a global one. 


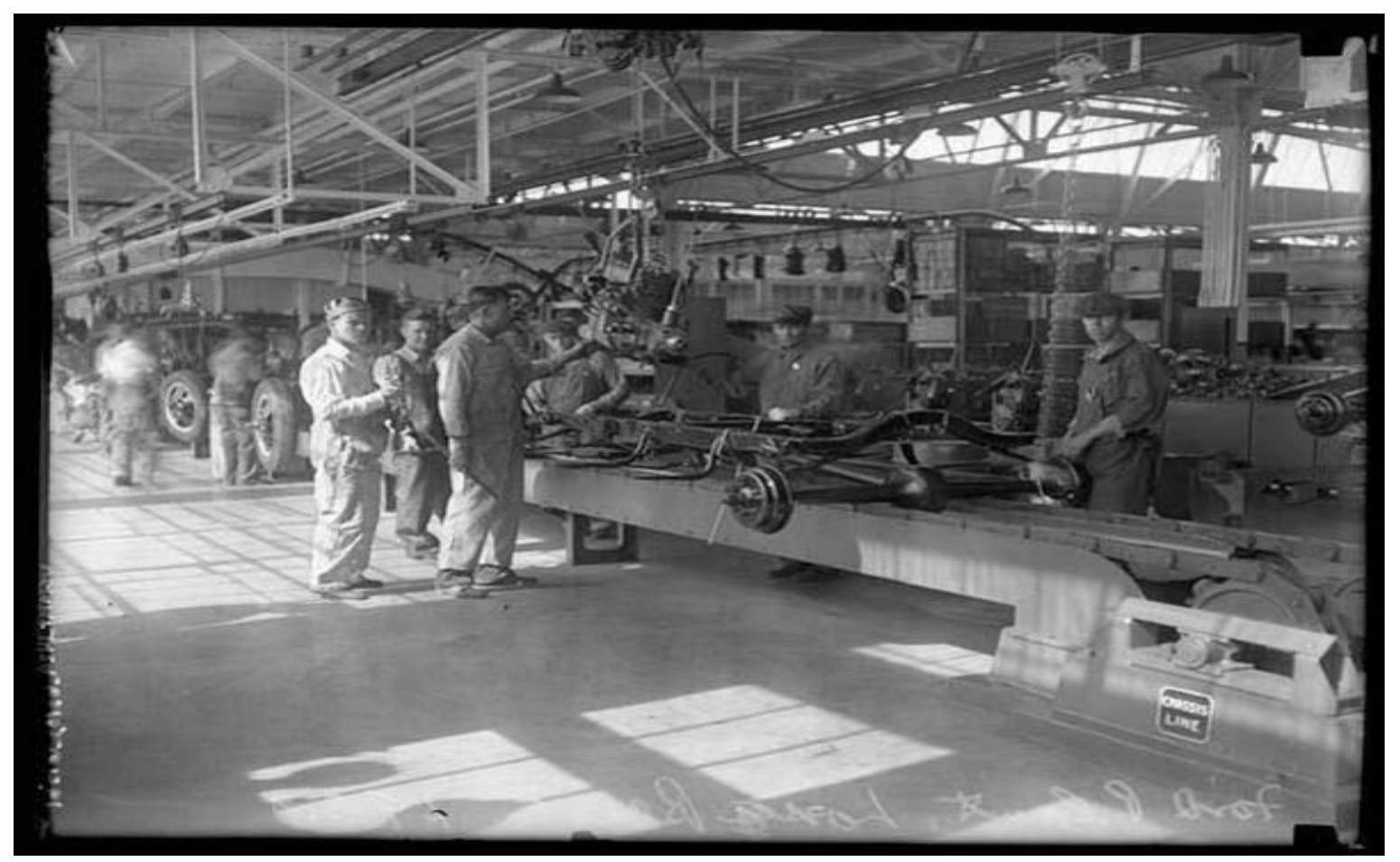

Figure 8 . The first car factory with an assembly line in the US (1926, Ford)

(source: Wikipedia, 1926)

3

\section{Current state}

Since 2007, the world has been facing financial crisis. Although it is assumed that it lasted until 2009, many EU countries have not yet successfully dealt with its consequences. One of the examples is Greece, which, since 2009, has not been able to handle its financial calamity. This condition is also referred to as the Greek financial crisis, and is serious enough to cover the remaining countries of the European Union, in particular those that make up the Euro zone. The global financial crisis has shown pointedly and unequivocally that services, in particular financial services, are not the best road to growth and stability of individual economies.

As a result of globalization, the top international companies from the industry sector, in search of a way to lower costs, moved production to a large extent beyond the US and Europe. The share of the GDP in industry dropped in the case of several EU countries and the US. However, the tendency to relocate manufacturing plants and production to China and Korea, where the labor force is cheap, is no longer as strong as it was over the past years. There are cases of Chinese businesses transferring their business processed abroad. An example here could be Lenovo, a Beijing-placed computer manufacturer, which in January 2013, launched a new assembly line in the US, where it puts together computers, tablets, working stations, and servers. The justification for such decision was the high position of the brand in the US market, which is why the company needs flexibility in gathering its products to be able to swiftly deliver them to its customers countrywide. It is still less costly to manufacture in China, even though pay rates there have been going up over the past few years. Nevertheless, the already shrunk gap allows companies to balance part of their labor costs by economizing on logistics (Innovation Union, 2015).

The US companies that have long had their plants overseas, take similar action. Caterpillar, General Electric, Apple, and Ford have announced plans to relocate some of their manufacturing operations back home, that is, to the US. Ford has even started bringing production back home from China and Mexico, following its agreement with United Auto Workers, 
a US labor union, which allowed them to employ The return of the industry is becoming a significant phenomenon, thanks to which one has to assume that more and more companies are making similar decisions. A clear benefit, apart from the shrinking pay gap between China and the US, is the growing productivity of the average US employee. Yet, the growing costs of transport, which is strictly connected to production, for example, in China, makes outsourcing more costly. Also, the growing extraction of shale gas gives the US the trump card of cheap energy, thanks to which the petrochemical industry will get even stronger.

All this may lead to making US factories more competitive within the next years, not just against Europe or Japan, but also against the gigantic Chinese industry. However, such change will most probably not mean that the US will again have 19 million manufacturing workers, just as it used to be back in 1980 . Automation and computerization are inherent trends giving rise to new jobs and workplaces, significantly different in nature, when juxtaposed with those that disappeared in the years 2000-2009. Yet, every major domestic production growth is a chance to boost innovation and enhance the economy.

It is commonly acknowledged that narrowing the pay gap between China and the US is a crucial factor underlying the return of the industry back to the US. China is getting richer, and its employees demand better pay; eventually, they get it. Until 2006, the difference in labor costs between the two countries stood at approx. 17 US dollars per hour. In 2015, it may, however, drop to a mere 7 US dollars per hour. Leaving production in the US will translate into lower costs of stock/reserve, and lower costs of transport. Production handled closer to the domestic market means manufacturing at a higher level of quality and maintaining a given technological regime.

This view seems to be grounded. In February 2012, the survey administered by Boston Consulting Group (BCG) (Żmijewski, 2014) revealed that $37 \%$ of US producers with sales volumes exceeding 1 billion US dollars admitted to having considered relocating part of their production from China to the US. Amidst the factors indicated were not just growing costs and pay-related benefits in China, but also the fact that new, less-paid so-called "second-tier" workers.

this country sets increasingly more restrictive labor regulations, which leads to more frequent industrial disputes, and industrial actions.

The research conducted by BCG also proves that the US enjoys all the conditions to lower their costs of production when compared to Europe and Japan within the next few years. Research also shows part of the industry may be, or already is, beginning to slowly migrate back to China. This trend covers segments, such as rubber and plastic, machinery and electrical equipment, computers, and electronics. Nissan, Honda, and Toyota are already suffering from the growth of export of their products from the US. In 2008, Ikea opened a new furniture factory in Danville (Virginia) to bring down shipping costs. Airbus, a European aviation company, has opened its new plant in Mobile (Alabama) (Plumer, 2013).

In Europe, an additional factor that has a negative impact on the condition of EU countries is the political situation of Eastern Europe. Criticizing Russia's actions taken in Ukraine led, above all, to the introduction of an embargo for Russia, which had negative repercussions within the EU economy. This, in turn, implies the need to carry out changes in order to stimulate the economy.

In order to reverse the present trends, the EU has approved relevant recommendations for actions striving to make domestic production increase its percentage share within the GDP. On 7 October 2012, the European Commission adopted a strategy of reindustrialization of the European Union, whose key goal is to increase the share of the industry in the EU's GDP from the current average level of 15.6 to $20 \%$ by 2020 . What is reindustrialization? Following Siemens, one of the largest German companies running industrial growth in the EU, it is "a gradual transformation within the branch structure of the industry from capital-consuming branches (i.e. ones with high requirements for resources, energy, and labor force) towards "intellectually intense" branches that require extensive engagement of science and highly skilled staff" (Żmijewski, 2014).

At the moment, in Europe, a lot of investments are halted due to an unstable situation in the market. The announced strategy is to radically improve this situation. 
The industry growth strategy rests on 4 pillars: investment in innovations, better market conditions. for example, improving the functioning of the internal market, increasing access to capital and human capital. The growing share of the industry in the EU will take place by decreasing the so-called "financial bubbles" (among others, in the real estate segment) and reducing the share of the public sector, rather than by decreasing the share of other sector in the GDP, for example, services. The decision to adopt such a strategy meets the expectations of EU countries. Germany, France, or Italy petitioned for the implementation of a recovery plan for the European industry.

In 1991, European states reached a 20\% level of industry - GDP share. However, due to low labor costs in China, many companies moved production indeed there. This brought about a drop in the share of the industry in the GDP across the EU to $15-16 \%$, although there are countries that already exceed $20 \%$, for example, Germany, France, or Denmark. The level the EU Commission strives to reach is doubtless attainable, but it requires from Europe massive investments in new technologies (Forbes, 2012).

One of many indicators used to illustrate the trends of industrial activity is the index of the numbers of working robots in selected countries (Table1, Żmijewski, 2014).

The tendency to replace human labor with industrial robots is a growing one, with big perspectives. It seems that given the unquestioned advantages of robots in industrial activity, increasing their areas of use in industry is clearly a developmental trend. Comparing the number of robots used in highly industrialized countries with numerous European countries, including Poland, shows a significant technical gap.

Table 1. The purchase and application rate of robots and manipulators

(source: Żmijewski, 2014)

\begin{tabular}{|c|c|c|c|}
\hline Year & $\begin{array}{c}\text { Global sales volume } \\
\text { of new industrial robots } \\
\text { (in thousands) }\end{array}$ & $\begin{array}{c}\text { Number } \\
\text { of business enterprises } \\
\text { in Poland equipped with robots }\end{array}$ & $\begin{array}{c}\text { Number of installed robots } \\
\text { and manipulators in Poland } \\
\text { (pieces) }\end{array}$ \\
\hline 2008 & 110 & 641 & 6267 \\
\hline 2009 & 60 & 725 & 7239 \\
\hline 2010 & 130 & 835 & 8021 \\
\hline 2011 & 165 & 910 & 9285 \\
\hline 2012 & 155 & 980 & 10,438 \\
\hline 2013 & 170 & - & - \\
\hline 2014 & 180 & - & - \\
\hline
\end{tabular}

In Poland, the so-called "density of robotization" reaches approx. 15-20 robots per 10,000 employees, that is, far below the world average, which is currently 55. In Japan or Korea, it goes up beyond 300 (Kampa, 2014). The existing gap between the number of robots applied in industry in diverse countries will go down in light of the progressing automation and computerization of production processes, forced among others by stiff competition in global markets.
The Fig. 9. presents industrial robots from an assembly of cars.

The incredibly fast growth of telecom, the Internet, and innovative computer technologies is itself a natural basis for technological and technical growth of the industry. The IT and telecom tools on offer will allow to effectively carry out reindustrialization of the industry. 
New goods and products will appear that will require a new approach to their manufacturing, the systems of their control, and post-sales servicing. All this seems to be confirmed by functioning satellites, unmanned spacecraft, first prototypes of autonomous cars, and drones.

The consequences of launching the strategy approved by the European Commission will be tough for some of the EU member states: mostly because of their diversified economic, social, and political situation, but also their readiness or courage to come to terms with change. Nevertheless, it seems that the global economic situation forces actors of the international stage to adopt such a solution. The planned reindustrialization will mostly entail applying innovative solutions within the manufacturing of new products. Such an approach will allow to perform a major civilizational leap in industrial production. The question is: how to do it? Well, one of the better known approaches to this challenge is Industrie $4.0-$ an innovative methodology that has its roots in Germany.

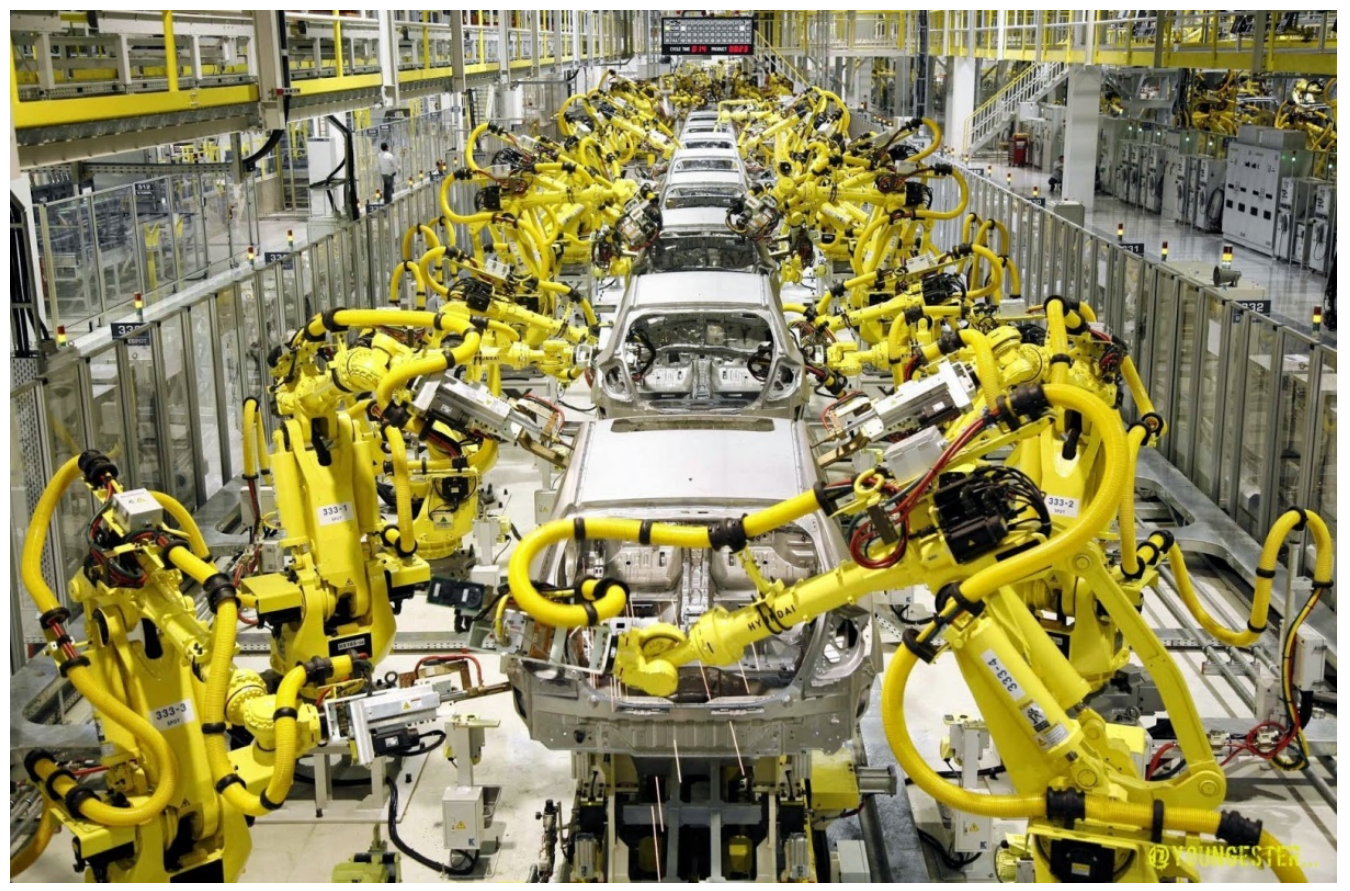

Figure 9. An assembly line of cars made up exclusively of industrial robots (source: Magazyn Przemysłowy, 2015)

\section{4}

The future of Industrie 4.0

Industrie 4.0 is a notion that specifies the set of technologies and concepts that constitute the vision of the industry of the future. Underlying Industrie 4.0 is the guarantee of bigger innovation, flexibility, and reliability along with top quality standards in engineering, planning, production, operation, and logistical processes. It will be possible due to, among others, a turbulent growth of IT technologies, Cloud computing, and others. It will facilitate social share in innovative processes in line with the following model: several minor authors of innovations acting in the convention of Internet communities and similar global industrial holdings putting these innovations into commercial practice. The application of this approach will lead to the creation of dynamic, self-organizing and real-time-optimizing chains of values. They will be able to be optimized on the basis of diverse criteria such as, for example, cost, availability, and use of resources. However, it will require appropriate regulatory frames. One of the basic problems will be that of leading to standardizing tools and communication interfaces as part of design processes (CAD/CAM-type tools), as well as modeling, and production control. The programmed changes will have a large impact on the required changes within the management of businesses and business processes. 
Works in this area are already conducted by, among others, Siemens PLM Software, or Dassault Systemes (Dassault Systemes, 2016; Ritholtz, 2010).

What then is Industrie 4.0? We shall illustrate it in Table 2 by comparing it (Table 2) with the current state of industrial growth (conventionally referred to as 3.8) (Bocian, Czyżewski and Nowakowski, 2015; Czasopismo tec.News, 2013; Evans and Annunziata, 2012; Ferber, 2013; Żmijewski, 2014).

Table. 2. Comparing Industrie 3.8 and 4.0

(source: individual elaboration)

\begin{tabular}{|l|l|}
\hline \multicolumn{1}{|c|}{ Industrie 3.8 } & \multicolumn{1}{c|}{ Industrie 4.0 } \\
\hline Local drives with IP address & Adaptation of local drives available via Internet \\
\hline Real-time communication with machinery drives & Standardized machine-machine communication \\
\hline $\begin{array}{l}\text { Digital model of products and its technological } \\
\text { process }\end{array}$ & Digital model of product/process and all system elements \\
\hline $\begin{array}{l}\text { Manufacturing Execution System, Enterprise Re- } \\
\text { source Planning }\end{array}$ & $\begin{array}{l}\text { Adaptive architecture of digital platform and manufactur- } \\
\text { ing system }\end{array}$ \\
\hline Industrial communication systems & Adaptive security mechanism \\
\hline Analyses and decisions made by employees & $\begin{array}{l}\text { Definition of rules and limits for product/process adapta- } \\
\text { tion, and manufacturing process/system }\end{array}$ \\
\hline & Industrial Internet \\
\hline & Intelligent product and machinery \\
\hline & Internet of things \\
\hline & Open platform: customers influencing the product \\
\hline
\end{tabular}

Table 3 presents the key pros and cons of areas connected to Industrie 4.0.

Table 3. Advantages and drawbacks of Industrie 4.0

(source: individual elaboration)

\begin{tabular}{|c|c|c|}
\hline Area & Advantages & Drawbacks (threats) \\
\hline $\begin{array}{l}\text { Internet } \\
\text { of things }\end{array}$ & $\begin{array}{l}\text { - linking the physical world to the world of digital } \\
\text { appliances, for example, remote reading of coun- } \\
\text { ters/meters } \\
\text { - surveillance of the environment } \\
\text { - surveillance of the repair of appliances } \\
\text { - remote control of appliances } \\
\text { - interaction between production machinery and the } \\
\text { manufactured goods/products }\end{array}$ & $\begin{array}{l}\text { - dependence upon digital appliances } \\
\text { - risk of losing key data } \\
\text { - risk of faulty operation of foreign } \\
\text { entities/bodies } \\
\text { - need to create proper infrastructure, } \\
\text { processing lots of data } \\
\text { - need to create secure communication }\end{array}$ \\
\hline
\end{tabular}


Table 3. Advantages and drawbacks of Industrie 4.0

(source: individual elaboration), cont.

\begin{tabular}{|c|c|c|}
\hline Area & Advantages & Drawbacks (threats) \\
\hline Society & $\begin{array}{l}\text { - elimination of people from numerous potentially } \\
\text { dangerous jobs/work } \\
\text { - elimination of people from routine work/jobs, } \\
\text { and concentrating their effort on creative actions } \\
\text { - adding new jobs and workplaces } \\
\text { - shortening people's working time at production } \\
\text { - people become a value (his/her creativity), and not } \\
\text { just a tool, as all production activities are performed } \\
\text { by machines } \\
\text { - bigger customers' impact on goods/products } \\
\text { - customers can determine their individual product } \\
\text { qualities, event during production }\end{array}$ & $\begin{array}{l}\text { - employees' fear of losing their job } \\
\text { - need to adapt to new working condi- } \\
\text { tions } \\
\text { - need to raise customer's awareness } \\
\text { that it pays off to give feedback } \\
\text { to the factory about a given product } \\
\text { in order to get a better one in the fu- } \\
\text { ture }\end{array}$ \\
\hline $\begin{array}{l}\text { Production } \\
\text { management }\end{array}$ & $\begin{array}{l}\text { - surveillance and control of production in real-time } \\
\text { conditions } \\
\text { - real-time changes in production } \\
\text { - manufacturing unique and small number of goods } \\
\text { with profit } \\
\text { - intelligent product contains information on how } \\
\text { to produce it, hence it can control its own production } \\
\text { process } \\
\text { - increasing the range of production automation } \\
\text { - new methods of production management due to the } \\
\text { real-time possibility to change production and use in- } \\
\text { formation from intelligent products }\end{array}$ & $\begin{array}{l}\text { - dependence on IT failures } \\
\text { - possibility of production control } \\
\text { takeover by hostile entities } \\
\text { - requires creating high quality real- } \\
\text { time applications }\end{array}$ \\
\hline Ecology & $\begin{array}{l}\text { - better supervision of emission of hazardous substanc- } \\
\text { es } \\
\text { - minimizing surplus production and one that is irrele- } \\
\text { vant to customers' needs } \\
\text { - better management of resource/product delivery }\end{array}$ & \\
\hline $\begin{array}{l}\text { Intelligent } \\
\text { products }\end{array}$ & $\begin{array}{l}\text { - product collects information about its life cycle } \\
\text { - product can inform about repair need, wear, etc. } \\
\text { - product informs about its life cycle, which allows } \\
\text { to improve product parameters and the processes } \\
\text { of its production }\end{array}$ & $\begin{array}{l}\text { - need to store masses of data } \\
\text { and analyzing them } \\
\text { - minor communication flaws between } \\
\text { the product and the plant may cause } \\
\text { large damage } \\
\text { - danger of pretending to be a given } \\
\text { product and injecting inaccurate data }\end{array}$ \\
\hline
\end{tabular}

The question of growth and implementation of Industrie 4.0 solutions in domestic economies has been subject to in-depth analyses in several countries. The country that has taken the most serious approach is Germany. In January 2012, they launched Industrie 4.0 Working Group, made up of numerous representatives of leading companies (among others
ThyssenKrup $A G, B M W A G$, Deutsche Software $A G$, Telekom $A G$, Daimler $A G, A B B A G$ ), representatives of top universities (among others TU Darmstad, TU München, University of Oldenburg, Jacobs University in Bremen, RWTH Aachen), research institutes/centers and representatives of the Ministries 
of the Economy and Technology, Education and Research, a group of high-level experts.

The working group organized a series of conferences and seminars dedicated to the notion of Industrie 4.0. April 2013 saw the publication of the final report of the group featuring recommendations for the implementation of Industrie 4.0. It proves a seri- ous involvement of industrial and academic circles in works connected to the growth and implementation of the Industrie 4.0 concept in German industry.

The Industrie 4.0 Working Group has conducted a number of studies. The graphs below (Fig. 10 and Fig. 11) illustrate the findings of two of these.

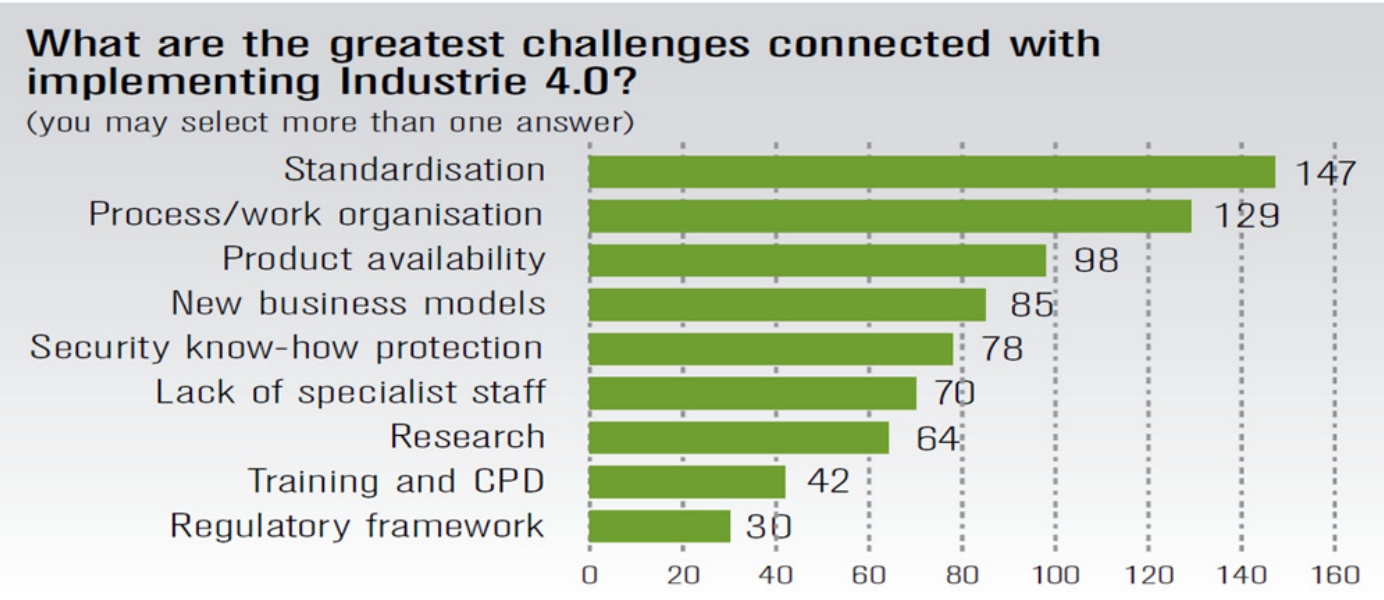

Figure 10. Top challenges in the Industrie 4.0 implementation (source: Industrie 4.0 Working Group, 2013)

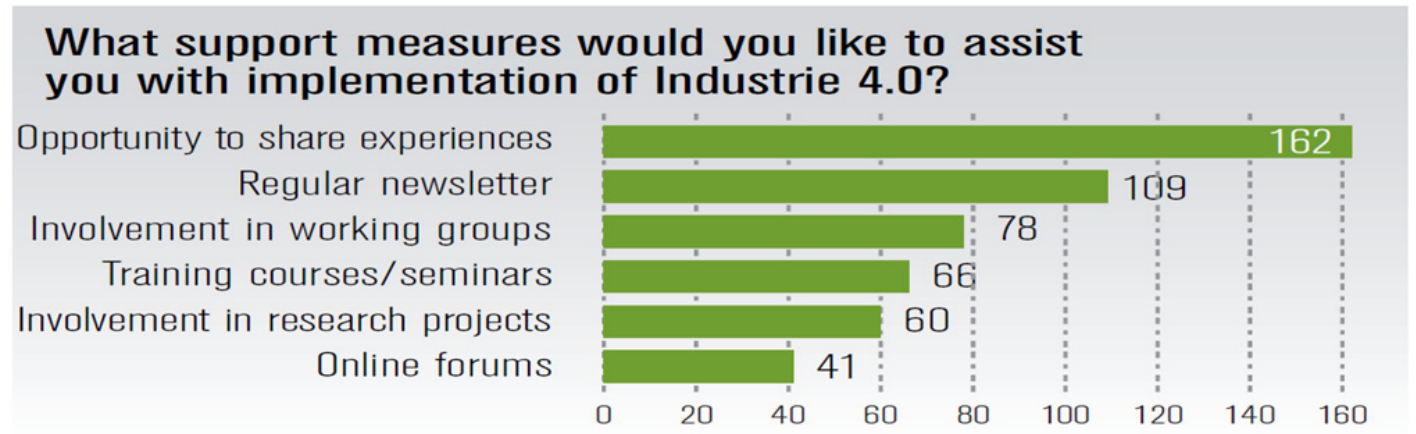

Figure 11. Top support means for Industrie 4.0 implementation (source: Industrie 4.0 Working Group, 2013)

\section{Conclusions}

Does a return to the industry make sense? Is Industrie 4.0 a good idea to attain this goal? Maybe, is it worth increasing perforce the size of industry by any possible means of financing, support, and discounts? We believe that in the face of a possible Third World War, economic expansion of China in Africa and Oceania (Agnosiewicz, 2014; Ma, 2014; PwC, 2016), instability of Arab countries, a strong and effective industry, mostly heavy, ought to be the cornerstone of each economy. One of the reasons for Poland's loss of independence and 123 years under partitions was its weak industry (Agnosiewicz, 2014).

Supported by Industrie 4.0, reindustrialization is already a fact. There are increasingly more technologies facilitating the implementation of intelligent productions and the creation of other ideas revolving around Industrie 4.0 (RFID, Ethernet, SoA, OPC$U A)$. 
What is more, these technologies are already used in the economy. Industrie 4.0 adds new jobs that require sophisticated know-how and high creativity. On the other hand, the number of dangerous workplaces is lowered.

The Industrie 4.0-style industry is one that is oriented at product individualization and the application of state-of-the-art technologies with outstanding perspectives for growth. Because of this, it is incredibly interesting and a real challenge for people who are creative and open to innovation. Quick and effective implementation of a new approach to products and their manufacturing process may place the EU in the leading position in the field of modern technologies, thus attracting capital, and talented and gifted people. Industrie 4.0 is also addressed at environental protection (Czasopismo tec.News, 2013; Industrie 4.0 Working Group, 2013).

In Poland, the concept of the growth and implementation of Industrie 4.0 so far does not arouse significant interest. Authors suggest to launch, just like the Germans did, a Working Team/Group dedicated to this issue with a view to disseminating the notion, supporting the development work, and presenting Industrie 4.0 implementations across research centers, industrial business enterprises, and academic centers. The work of such a group could effectively support the activity of industrial enterprises striving for effective rivalry in the global market. A key area of the Group's activity ought to be training and information. More technological parks should be set up in order to attract people's attention with the notion of state-of-the-art technologies and to allow them to conduct research on them and their growth.

\section{Bibliography}

[1] Agnosiewicz M., 2014. Chińskie inwestycje w Malezji (Chinese investments in Malaysia). [online] Available at:

$<$ http://www.racjonalista.pl/kk.php/s,9779>

[Accessed: 3 March 2016].

[2] Agnosiewicz M., 2014. Dzieło polskiego Oświecenia wykuwano w kuźnicach, nie w salonach literackich (The deed of the Polish Enlightenment was hammered in forges, rather than in literary salons). [online] Available at: $<$ http://www.racjonalista.pl/kk.php/s,9758

[Accessed: 5 March 2016].

[3] Bocian K., Czyżewski P., Nowakowski Ł., 2015. Wykorzystanie koncepcji Industrie 4.0 do celów dydaktycznych na Politechnice Warszawskiej z zastosowaniem produktów Siemens Industrie Software (Using the concept of Industrie 4.0 for didactic purposes at Warsaw University of Technology, along with Siemens Industrie Software products), Politechnika Warszawska (Warsaw University od Technology).

[4] Czasopismo tec.News, 2013. Integrated Industry. Jak produkty będa sterować produkcja w przyszłości (How will products control production in the future?). (Czasopismo tec.News publication 25) [online] tec.News (published 2013) Available at:

$<$ http://www.harting.com/en/news/publications/t echnology-newsletter-tecnews/tecnews-issue25> [Accessed: 2016.03.06].

[5] Dassault Systemes, 2016: Dassault Systèmes and DCNS. [online] Available at:

$<$ http://www.3ds.com/>

[Accessed 6 March 2016].

[6] Eurostat, 2016. Dane o krajach (PKB) (Data on countries $(G D P))$. [online] Available at: $<$ http://ec.europa.eu/eurostat/data/database $>$ [Accessed 3 March 2016].

[7] Evans P.C., Annunziata M., 2012. Industrial Internet: Pushing the Boundaries of Minds and Machines. [online] Available at:

$<\mathrm{http}: / /$ www.slideshare.net/GE_MC_India/indus trial-internet-pushing-the-boundaries-of-mindsand-machines $>$ [Accessed 1 March 2016].

[8] Ferber S., 2013. Industry 4.0 - Technology for the Fourth Industrial Revolution. Berlin.

[9] Forbes, 2012. Reindustrializacja Europy sposobem na kryzys (Europe's reindustrialisation a remedy for the crisis). [online] Available at: $<$ http://www.forbes.pl/artykuly/sekcje/Wydarzen ia/reindustrializacja-europy-sposobem-nakryzys,30663,1> [Accessed 5 March 2016].

[10] GeoGrześ, 2010. Trzecia rewolucja przemystowa (The Third Industrial Revolution). [online] Available at: 
$<$ http://geogrzes.blog.onet.pl/2010/12/29/trzeciarewolucja-przemyslowa>

[Accessed: 5 March 2016].

[11] Global Finance, 2016. Podziat PKB kraju na sektory gospodarki (The subdivision of a country's GDP into sectors of the economy). [online] Available at: <https:/www.gfmag.com/globaldata/country-data/the-european-union-gdpeconomic-report> [Accessed 26 March 2016].

[12] Gouardères F., 2016. Ogólne zasady unijnej polityki przemystowej (General principles of the EU industrial policies). [online] Available at: http://www.europarl.europa.eu/aboutparliament/ $\mathrm{pl} /$ displayFtu.html?ftuId=FTU_5.9.1.html [Accessed 2 March 2016].

[13] Index Mundi, 2015. Dane o krajach (PKB) (Data on countries $(G D P))$. [online] Available at: $<$ http://www.indexmundi.com/g/g.aspx? $\mathrm{v}=67 \& \mathrm{c}$ $=\mathrm{ch} \& \mathrm{c}=\mathrm{ee} \& \mathrm{c}=\mathrm{fr} \& \mathrm{c}=$ in $\& \mathrm{c}=\mathrm{sa} \& \mathrm{l}=\mathrm{en}>$

[Accessed: 26 March 2016].

[14] Industrie 4.0 Working Group, 2013. Recommendations for implementing the strategic initiative INDUSTRIE 4.0. Berlin: Industrie 4.0 Working Group.

[15] Innovation Union, 2015, Innovation Union Scoreboard 2014. [online] Available at: $<$ http://ec.europa.eu/enterprise/policies/innovatio n/files/ius/ius-2014_en.pdf> [Accessed 15 March 2016].

[16] Kampa A., 2014. Ekonomiczne uwarunkowania robotyzacji procesów produkcyjnych (Economic foundations of the robotisation of manufacturing processes). Zarządzanie Przedsiębiorstwem nr 3 (2014), kwartalnik Polskiego Towarzystwa Zarządzania Produkcją.

[17] Komisja Europejska (UE Commission) Statement CSST/2014/5489 of 22 January 2014 Dziatania na rzecz odrodzenia przemystu europejskiego (Acting for the benefit of the rebirth of European industry.

[18] Komisja Europejska, 2011. Polityka przemystowa - poprawa konkurencyjności (Industrial policy - improving competitiveness). [online] Available at:

$<$ http://orka.sejm.gov.pl/SUEVIkad.nsf/Plikizal/COM_2011_642_PL_ACTE_f.pdf/\$file/CO M_2011_642_PL_ACTE_f.pdf>

[Accessed 15 March 2016].
[19] Komisja Europejska, 2012. Silniejszy przemyst europejski na rzecz wzrostu $i$ ożywienia gospodarczego - Aktualizacja komunikatu w sprawie polityki przemystowej (Stronger European industry for the growth and economic animation An update of the communication on industrial policy). [online] Available at:

$<$ http://eurlex.europa.eu/LexUriServ/LexUriServ .do?uri=COM:2012:0582:FIN:EN:PDF> [Accessed 15 March 2016].

[20] Ma M., 2014. 8 Facts about China's Investments in Africa (Acting for the benefit of the rebirth of European industry). [online] Available at: $<$ http://www.brookings.edu/blogs/brookingsnow/posts/2014/05/8-facts-about-chinainvestment-in-africa $>$ [Accessed: 5 March 2016].

[21] Magazyn Przemysłowy, 2015. Zrobotyzowana linia produkcyjna (Robotised production line). [image online] Available at: $<$ http://www.magazynprzemyslowy.$\mathrm{pl} /$ img/89/robot-integration5ae1e52b29947440a5773d58cdef9aee.jpg> [Accessed: 5 March 2016].

[22] Plumer B., 2013. Is U.S. manufacturing making a comeback - or is it just hype? [online] Available at:

$<$ http://www.washingtonpost.com/blogs/wonkbl og/wp/2013/05/01/is-u-s-manufacturing-set-fora-comeback-or-is-it-all-hype/> [Accessed: 5 March 2016].

[23] PwC, 2016. China's war on water scarcity. [online] Available at:

$<$ http://www.pwc.com/gx/en/capital-projectsinfrastructure/chinas-infrastructure-investmentin-africa.jhtml $>$ [Accessed: 5 March 2016].

[24] Ritholtz B., 2010. Historia PKB (The history of the GDP). [online] Available at: $<$ http://www.ritholtz.com/blog/2010/-08/historyof-world-gdp/> [Accessed: 20 February 2016].

[25] Siemens PML Software, 2016. Siemens PML Software. [online] Available at:

$<$ http://www.plm.automation.siemens.com/pl_pl > [Accessed: 6 March 2016]. 
[26] Wikipedia, 2015. Lista krajów z informacja o PKB (The list of countries with data on GDP). [online] Available at:

$<$ http://en.wikipedia.org/wiki/List_of_countries by_GDP_sector_composition> [Accessed: 2 March 2016].

[27] Wikipedia, 1926. Zdjęcie fabryki Forda (Photo of the Ford plant). [image online] Available at: $<\mathrm{http}$ ://images.viralnova.-

com/000/038/803/historical-photos5.jpg $>$ [Accessed: 5 March 2016].
[28] Żmijewski R., 2014. Siemens Industry Software: Elementy koncepcji Industrie 4.0 w praktyce Systemowe modelowanie produktu $w$ wirtualnym przedsiębiorstwie (Elements of the Industrie 4.0 concept in practice; System-based product modelling in a virtual enterprise). [online] Available at: $\quad<$ http://docplayer.pl/14404076-Elementykoncepcji-industrie-4-0-w-praktyce-systemowemodelowanie-produktu-w-wirtualnym-

przedsiebiorstwie.html> [Accessed: 7 March 2016] 